\title{
Nutritional Status and Total Phenols of Passiflora Genotypes Related to Nitrogen Fertilization
}

\author{
Renata Vianna Lima, Almy Junior Cordeiro de Carvalho, Paulo Cesar Santos, \\ Jalille Amim Altoé Freitas, Mírian Peixoto Soares da Silva, Silvio de Jesus Freitas, \\ Marta Simone Mendonça Freitas \\ Universidade Estadual do Norte Fluminense Darcy Ribeiro, Campos dos Goytacazes, Brazil \\ Email: renataviannalima2005@yahoo.com.br
}

Received 19 January 2015; accepted 17 March 2015; published 19 March 2015

Copyright (C) 2015 by authors and Scientific Research Publishing Inc.

This work is licensed under the Creative Commons Attribution International License (CC BY). http://creativecommons.org/licenses/by/4.0/

(c) (i) Open Access

\section{Abstract}

This paper was developed in order to verify the influence of nitrogen fertilization and different genotypes in the nutritional aspect and in the production of total phenols in passifloraceae. The experimental design was randomized blocks in a $5 \times 2 \times 2$ factorial scheme, being five genotypes of Passiflora (three genotypes of Passiflora edulis, a genotype of Passiflora alata and a genotype of Passiflora ligularis), two levels of cow manure (with and without) and two doses of $\mathrm{N}(20$ and $80 \mathrm{~g})$, with four replicates. At 120 days after sowing, levels of foliar nutrient and total phenols were determined. Foliar $\mathbf{N}$ content varied depending on $\mathrm{N}$ doses, organic fertilization and the genotypes used. Foliar levels of $P$ and $K$ were higher when all genotypes received organic fertilization, while the levels of Fe and Mn were similar regardless of this fertilization. The levels of Ca and Mg were higher related to organic fertilization and the genotypes, in isolation. But the foliar contents of $S$, $\mathrm{Zn}$ and $\mathrm{Cu}$ increased only in relation to the used genotypes, and the average foliar content of total phenols found was $19.4 \mathrm{~g} \cdot \mathrm{kg}^{-1}$, ranging from 13.1 to $23.2 \mathrm{~g} \cdot \mathrm{kg}^{-1}$, being the lowest value observed in Passiflora alata without fertilization with cow manure. It is concluded that the nutritional requirement for $\mathrm{N}$ is greater for genotypes of the species Passiflora edulis in relation to the species Passiflora alata and Passiflora ligulares, and that the organic fertilization influences positively in the production of total phenols only for the genotype of sweet passion fruit.

\section{Keywords}

Fertilization, Nitrogen, Secondary Metabolites, Nutrients 


\section{Introduction}

Passion fruit is a fruit species of great economic importance, being consumed both in the fresh and processed forms [1], in addition to presenting potential for extraction of secondary metabolites [2], as total phenols, which have antioxidant properties [3]. Although these compounds are genetically controlled, their quality and quantity [4] can be influenced by several factors; the plant nutrition is among them [4]-[7].

Fertilizer practice requires knowledge of the plant morphophysiological characteristics and soil nutrient availability to their effect in the plant, and the nutrients can be provided through organic and mineral fertilization [8].

Among the nutrients provided via fertilization, nitrogen is the one which deserves attention because it takes part in many compounds considered indispensable for the growth and development of plants [9]. For yellow passion fruit, nitrogen is one of the most required nutrients [7] [10] and as verified by [6], in sweet passion fruit, its deficiency causes a variety of symptoms, even in fruits, bringing huge economic losses.

Studies have reported the effects of nitrogen fertilization on improving the quality of yellow passion fruit, such as reduction of the skin diameter and increase of soluble solids [11]. At the same time, [12] reported that organic fertilization has provided an increase on average weight of yellow passion fruits similar to plants subjected to conventional chemical fertilization.

However, the nitrogenous sources and cow manure fertilizations for species $P$. alata and $P$. ligularis are still unknown, mainly with respect to mineral nutrition and phenolic compounds production, being used as a parameter-the recommendation of $P$. edulis.

In this sense, the objective of this work was to verify the influence of mineral and organic nitrogen fertilization on mineral composition and total phenols production of five Passiflora genotypes.

\section{Material \& Methods}

The experiment was conducted in the area of the experimental station of the Universidade Estadual do Norte Fluminense Darcy Ribeiro (UENF), in the municipality of Campos dos Goytacazes-RJ (May-September, 2008), at an elevation of $11 \mathrm{~m}$ above sea level $\left(21^{\circ} 15^{\prime} 45^{\prime \prime}\right.$ South and $\left.41^{\circ} 19^{\prime} 28^{\prime \prime} W e s t\right)$. During the experiment period, monthly minimum temperature ranged from $16.1^{\circ} \mathrm{C}$ to $19.9^{\circ} \mathrm{C}$, the average temperature was $18.3^{\circ} \mathrm{C}$ and the maximum monthly temperature ranged from $27.3^{\circ} \mathrm{C}$ to $29.2^{\circ} \mathrm{C}$ with an average of $28.2^{\circ} \mathrm{C}$ and the precipitation ranged from 3.5 to $63.8 \mathrm{~mm}$.

The experimental design was a randomized complete block in a $5 \times 2 \times 2$ factorial scheme, being five genotypes of Passiflora [three genotypes of Passiflora edulis (passion fruit grown, Progeny 0304 and Progeny 2904), a genotype of Passiflora alata and a genotype of Passiflora ligularis], two types of organic fertilization (presence and absence of cow manure in the substrate) and two nitrogen doses (20 and $\left.80 \mathrm{~g} \cdot \mathrm{box}^{-1}\right)$ [13] provided in the form of urea, with four replicates and four plants per plot.

Yellow passion fruit seeds (P. edulis) improved from two progenies of half-brothers (0304 and 2904) acquired from the germoplasm bank of UENF and seeds of passion fruit grown in the region were used. While, sweet passion fruit seeds (P. alata) and seeds of Granadilla passion fruit (P. ligularis), were obtained from fruits of commercial lots.

The seeds of the Passiflora genotypes have been extracted from fruits and placed to germinate in boxes of 55 $\mathrm{cm}$ long, $37 \mathrm{~cm}$ wide and $30 \mathrm{~cm}$ high, which were filled with two substrates according to treatments. The first substrate was composed of a mixture of soil, sand and cow manure (1:1:1-v/v) and the second substrate was composed of a mixture of soil and sand (1:1-v/v). Chemical analysis of substrates was performed at the experiment deployment phase and presented the following features (Table 1).

Fifteen seeds of each genotype of Passiflora were seeded directly in cultivation boxes $(55 \mathrm{~cm}$ long, $37 \mathrm{~cm}$ wide and $30 \mathrm{~cm}$ high). After germination, the thinning was carried out leaving only two plants per box.

The plants were conducted in the open in a vertical trellis system, with a wire, $2 \mathrm{~m}$ height above ground level, with fence posts spacing of $6 \mathrm{~m}$, adopting the curtain system. For this, two target pruning of branches were performed, the first was carried out when the plant has reached $15 \mathrm{~cm}$ above the wire (primary branch pruning), when the branches were forced to develop laterally in opposite directions and fixed in a horizontal position the direction of the wires, and the second pruning was carried out when secondary branches of the plants were had reached one another.

Sixty days after seeds germination, nitrogen fertilization began, and the doses of each treatment were splitted 
Table 1. Chemical analysis of substrates performed at the experiment deployment phase.

\begin{tabular}{|c|c|c|c|c|c|c|c|c|}
\hline \multirow{2}{*}{ Substratum } & $\mathrm{pH}$ & $\mathrm{P}$ & $\mathrm{K}$ & $\mathrm{Ca}$ & $\mathrm{Mg}$ & $\mathrm{Al}$ & $\mathrm{H}+\mathrm{Al}$ & $\mathrm{Na}$ \\
\hline & $\left(\mathrm{H}_{2} \mathrm{O}\right)$ & $\left(\mathrm{mg} \cdot \mathrm{dm}^{-3}\right)$ & \multicolumn{6}{|c|}{$\left(\mathrm{mmolc} \cdot \mathrm{dm}^{-3}\right)$} \\
\hline 1 & 6.4 & 114 & 37 & 37.5 & 34 & 0 & 14.8 & 2.4 \\
\hline 2 & 5.9 & 13 & 1.5 & 23.4 & 12.4 & 0 & 24 & 0.5 \\
\hline \multirow{2}{*}{ Substratum } & $\mathrm{C}$ & MO & СTC & SB & $\mathrm{S}-\mathrm{SO}_{4}$ & $\mathrm{Fe}$ & $\mathrm{Cu}$ & $\mathrm{Zn}$ \\
\hline & \multicolumn{2}{|c|}{$\left(\mathrm{g} \cdot \mathrm{dm}^{-3}\right)$} & \multicolumn{2}{|c|}{$\left(\mathrm{mmolc} \cdot \mathrm{dm}^{-3}\right)$} & \multicolumn{4}{|c|}{$\left(\mathrm{mg} \cdot \mathrm{dm}^{-3}\right)$} \\
\hline 1 & 30.7 & 52.9 & 125.7 & 110.9 & 51 & 69.9 & 0.71 & 8.91 \\
\hline 2 & 11.5 & 19.83 & 61.8 & 37.8 & 9 & 279.7 & 1.72 & 4.26 \\
\hline \multirow{2}{*}{ Substratum } & & $\mathrm{Mn}$ & & & & B & & \\
\hline & \multicolumn{8}{|c|}{$\left(\mathrm{mg} \cdot \mathrm{dm}^{-3}\right)$} \\
\hline 1 & & 25.5 & & & & 0.69 & & \\
\hline 2 & & 15.4 & & & & 0.50 & & \\
\hline
\end{tabular}

monthly, totaling 10 applications.

At 120 days after sowing, a plant per box of each treatment was collected. Then the leaves were separated from plants, and they were put to dry in an oven with forced air circulation at $70^{\circ} \mathrm{C}$ for 72 hours. Subsequently, the levels of nitrogen $(\mathrm{N})$, phosphorus $(\mathrm{P})$, potassium $(\mathrm{K})$, calcium $(\mathrm{Ca})$, magnesium $(\mathrm{Mg})$, sulfur $(\mathrm{S})$, copper $(\mathrm{Cu})$, zinc $(\mathrm{Zn})$, iron $(\mathrm{Fe})$ and manganese $(\mathrm{Mn})$ were determined.

Plant material was subjected to oxidation by sulfuric digestion in order to determine the levels of $\mathrm{N}, \mathrm{P}$ and $\mathrm{K}$. $\mathrm{N}$ was determined by Nessler method [14], $\mathrm{P}$ by molybdate colorimetric method and $\mathrm{K}$ by flame emission spectrophotometry (spectrometry). Plant material has undergone nitric-perchloric acid digestion for determining the levels of $\mathrm{Ca}, \mathrm{Mg}, \mathrm{S}, \mathrm{Cu}, \mathrm{Zn}, \mathrm{Fe}$ and $\mathrm{Mn}$. The $\mathrm{Ca}, \mathrm{Mg}, \mathrm{Cu}, \mathrm{Zn}, \mathrm{Fe}$ and $\mathrm{Mn}$ were quantified by atomic absorption spectrometry and the $\mathrm{S}$ by turbidimetry with barium chloride.

The total phenols (soluble phenols, condensed and hydrolysable tannins, and non-tannin phenols) have been determined by the Folin-Denis method, in basic medium, from a sample of $0.75 \mathrm{~g}$ of plant material mixed with $20 \mathrm{~mL}$ of methanol $50 \%$, kept at a temperature of $80^{\circ} \mathrm{C}$ for one hour, using tannic acid as standard, as described by [15].

The data were subjected to analysis of variance through $\mathrm{F}$ test and the averages were compared by Tukey test $(\mathrm{P}<0.05)$.

\section{Results \& Discussions}

It was observed that only the genotype of Granadilla showed lower $\mathrm{N}$ content in the leaves, when grown in substrate fertilized with cow manure and with $20 \mathrm{~g} \mathrm{~N}$. This genotype obtained foliar $\mathrm{N}$ content similar to other genotypes (Table 2) when a dose of $80 \mathrm{~g} \mathrm{~N}$ was applied and independently of manure application.

The lack of response to organic fertilization may be associated with the slow mineralization process in the plants. On the other hand, according to [16], the certain amount of N quickly released in the initial stage of crop waste decomposition would be associated with the loss of fractions of this water-soluble nutrient.

The genotypes of the species $P$. edulis grown on substrate without cow manure and adding a dose of $80 \mathrm{~g} \mathrm{~N}$ presented greater $\mathrm{N}$ contents in foliar dry matter. While, the species $P$. alata and $P$. ligularis showed average levels $16.6 \%$ and $33.0 \%$ lower, respectively, in relation to genotype of cultivated passion fruit (Table 2).

Most of the works have compared the mineral composition of the species $P$. alata and $P$. ligularis with the species $P$. edulis, because for this last species there is already the optimal range for nutritional levels. [10], at 127 days after sowing $P$. edulis, observed the average foliar content of $49.9 \mathrm{~g} \cdot \mathrm{kg}^{-1} \mathrm{~N}$. However, it was observed in this work that the genotypes of the species $P$. alata and $P$. ligularis are less $\mathrm{N}$ demanding, since there was no increment in foliar levels of this nutrient even with increased dose of $\mathrm{N}$, which therefore, can reduce the use of nitrogen fertilization.

Granadilla genotype presented the lowest $\mathrm{P}$ content $\left(1.06 \mathrm{~g} \cdot \mathrm{kg}^{-1}\right)$ in leaf dry mass when grown on a substrate 
Table 2. Nitrogen content in the leaves of genotypes of passion fruit, according to nitrogen $(\mathrm{N})$ doses, grown with or without cow manure, at 120 days after sowing.

\begin{tabular}{|c|c|c|c|c|c|c|}
\hline \multirow{3}{*}{$\begin{array}{l}\text { Genotypes of } \\
\text { passion fruit }\end{array}$} & \multicolumn{6}{|c|}{ Nitrogen $\left(\mathrm{g} \cdot \mathrm{kg}^{-1}\right)$} \\
\hline & \multicolumn{2}{|c|}{$20 \mathrm{~g} \cdot \mathrm{N} \cdot \mathrm{box}^{-1}$} & \multirow{2}{*}{ Average } & \multicolumn{2}{|c|}{$80 \mathrm{~g} \cdot \mathrm{N} \cdot \mathrm{box}^{-1}$} & \multirow{2}{*}{ Average } \\
\hline & $\begin{array}{l}\text { Without } \\
\text { manure }\end{array}$ & With manure & & $\begin{array}{l}\text { Without } \\
\text { manure }\end{array}$ & $\begin{array}{l}\text { With } \\
\text { manure }\end{array}$ & \\
\hline Cultivated passion fruit & 36.7Aa & 35.7Аа & 36.2 & $50.5 \mathrm{Aa}$ & $44.5 \mathrm{Ba}$ & 47.5 \\
\hline Progeny 0304 & 35.8Aa & 35.3Аа & 35.6 & 52.0Aa & 39.7Bab & 45.9 \\
\hline Progeny 2904 & 35.1Aa & 33.6Аа & 34.4 & 52.2Aa & $35.4 \mathrm{Bb}$ & 44.0 \\
\hline Sweet passion fruit & 35.1Aa & 32.8Aa & 33.9 & $42.1 \mathrm{Ab}$ & $33.9 \mathrm{Bb}$ & 37.7 \\
\hline Granadilla & 39.1Аa & 30.4Ba & 34.8 & 33.8Ac & 33.9Ab & 33.8 \\
\hline Average & 36.4 & 33.6 & 34.9 & 46.1 & 37.4 & 41.8 \\
\hline C.V. (\%) & & & & & & \\
\hline
\end{tabular}

C.V. = Coefficient of variation; the averages followed by the same uppercase letter in the column and lowercase letter on the line, do not differ significantly based on the Tukey test $(\mathrm{p}<0.05)$.

without addition of cow manure. While the genotypes cultivated passion fruit and sweet passion fruit presented higher P contents in leaf dry mass when they received fertilizing with cow manure. The application of cow manure incremented leaf P levels of all genotypes except the Progeny 2904 (Table 3).

Carvalho [13] have defined that the optimal $\mathrm{P}$ contents for the species $P$. edulis are in the range from 2.31 to $3.85 \mathrm{~g} \cdot \mathrm{kg}^{-1}$. Moraes [17] obtained, for the same species, at 145 days after planting in the field, levels ranging from 2.14 to $3.01 \mathrm{~g} \cdot \mathrm{kg}^{-1}$. Considering these ranges, it is suggested that $\mathrm{P}$ content obtained in this experiment for this species is not in the proper range (Table 3 ).

Genotypes of Granadilla and cultivated passion fruit showed higher foliar K levels compared to other genotypes, when they were not fertilized with cow manure. On the other hand, when cow manure was added to the substrate, it was found that the genotypes of cultivated passion fruit, Progeny 0304, Progeny 2904 and sweet passion fruit presented increments of 92.0\%; 121.8\%; 72.8\% and 77.6\%, respectively (Table 3).

Although the addition of cow manure to cultivation substrate has increased the levels of $\mathrm{K}$ in leaf dry mass, these are still below those described by [10] and by [17]. According to the authors, the ranges for K in leaf dry mass are 34.8 - 37.5 and $33.5-38.7 \mathrm{~g} \cdot \mathrm{kg}^{-1}$, respectively, for the species $P$. edulis.

Average levels of $\mathrm{K}$ were also smaller than those found by [7] at 75 days when assessing the species $P$. alata and P. ligularis, which showed the levels of 23.2 and $25.7 \mathrm{~g} \cdot \mathrm{kg}^{-1}$, respectively, even when cow manure was applied.

Rosolem [18] reported that $\mathrm{K}$ and other nutrients, regardless of organic matter decomposition, can be intensively leached from the soil profile, being subject to rainfall intensity, quantity applied of nutrient and soil texture. Thus, the rainy condition found during the evaluation phase of this work may have favored the leaching of $\mathrm{K}$ and impaired its absorption by plants.

Progeny 2904 presented greater foliar Ca content in relation to the genotype of sweet passion fruit (Table 4). Foliar Ca levels were the same for all tested genotypes of $P$. edulis and these were higher than the contents of this element found in other studies by [19], by [13] and by [17]. On the other hand, these results agree with those found by [10], when they evaluated the initial growth of $P$. edulis.

For plants of the species $P$. ligularis, [7] verified that these, when grown in the presence of cow manure, showed levels of foliar $\mathrm{Ca}$ of $11.9 \mathrm{~g} \cdot \mathrm{kg}^{-1}$, at 77 days after transplanting.

It was found that $\mathrm{Mg}$ content in the leaves of the genotype Granadilla was 20\% higher than the leaf content found in the cultivated passion fruit (Table 4). On the other hand, the genotype Granadilla presented the lowest $\mathrm{S}$ content $\left(1.55 \mathrm{~g} \cdot \mathrm{kg}^{-1}\right)$ in leaf dry mass in relation to other genotypes (Table 4). This value is less than the content of $\mathrm{S}$ observed by [7] in plants of $P$. ligularis at 77 days after transplanting.

The genotypes of Passiflora when fertilized with cow manure presented an increase of $25 \%$ and $21.8 \%$ in levels of foliar $\mathrm{Ca}$ and $\mathrm{Mg}$, respectively, in comparison with the genotypes non-fertilized with cow manure (Table 5). The largest accumulations of these nutrients were observed when cow manure was applied on substrate, 
Table 3. Phosphorus and potassium contents in leaves of genotypes of passion fruit grown with or without cow manure, at 120 days after sowing.

\begin{tabular}{|c|c|c|c|c|c|c|}
\hline \multirow{2}{*}{$\begin{array}{l}\text { Genotypes of } \\
\text { passion fruit }\end{array}$} & \multicolumn{2}{|c|}{ Phosphorus $\left(\mathrm{g} \cdot \mathrm{kg}^{-1}\right)$} & \multirow{2}{*}{ Average } & \multicolumn{2}{|c|}{ Potassium $\left(\mathrm{g} \cdot \mathrm{kg}^{-1}\right)$} & \multirow{2}{*}{ Average } \\
\hline & Without manure & With manure & & Without manure & With manure & \\
\hline Cultivated passion fruit & $1.77 \mathrm{Ba}$ & 2.24Aab & 2.01 & 12.6Bab & $24.2 \mathrm{Aa}$ & 18.4 \\
\hline Progeny 0304 & $1.64 \mathrm{Ba}$ & $2.20 \mathrm{Ab}$ & 1.92 & $9.6 \mathrm{Bb}$ & 21.3Aab & 15.5 \\
\hline Progeny 2904 & $1.85 \mathrm{Aa}$ & $2.11 \mathrm{Ab}$ & 1.98 & $10.3 \mathrm{Bb}$ & $17.8 \mathrm{Ab}$ & 14.0 \\
\hline Sweet passion fruit & $1.66 \mathrm{Ba}$ & 2.70Aa & 2.18 & $9.4 \mathrm{Bb}$ & 16.7Ab & 13.0 \\
\hline Granadilla & $1.06 \mathrm{Bb}$ & $2.00 \mathrm{Ab}$ & 1.53 & 16.6Aa & $17.4 \mathrm{Ab}$ & 17.0 \\
\hline Average & 1.60 & 2.25 & & 11.7 & 19.5 & \\
\hline C.V. (\%) & & 17.3 & & & 23.2 & \\
\hline
\end{tabular}

C.V. = Coefficient of variation; the averages followed by the same uppercase letter in the column and lowercase letter on the line, do not differ significantly based on the Tukey test $(\mathrm{p}<0.05)$.

Table 4. Foliar levels of calcium, magnesium, sulfur, zinc and copper related to genotypes of passion fruit, at 120 days after sowing, regardless of the nitrogen treatments.

\begin{tabular}{cccccc}
\hline Genotypes of passion fruit & $\begin{array}{c}\text { Calcium } \\
\left(\mathrm{g} \cdot \mathrm{kg}^{-1}\right)\end{array}$ & $\begin{array}{c}\text { Magnesium } \\
\left(\mathrm{g} \cdot \mathrm{kg}^{-1}\right)\end{array}$ & $\begin{array}{c}\text { Sulfur } \\
\left(\mathrm{g} \cdot \mathrm{kg}^{-1}\right)\end{array}$ & $\begin{array}{c}\text { Zinc } \\
\left(\mathrm{mg}^{-1} \mathrm{~kg}^{-1}\right)\end{array}$ & $\begin{array}{c}\text { Copper } \\
\left(\mathrm{mg}^{-1} \mathrm{~kg}^{-1}\right)\end{array}$ \\
\hline Cultivated passion fruit & $17.2 \mathrm{ab}$ & $7.39 \mathrm{~b}$ & $2.34 \mathrm{a}$ & $30.1 \mathrm{ab}$ & $6.04 \mathrm{a}$ \\
Progeny 0304 & $18.6 \mathrm{ab}$ & $7.78 \mathrm{ab}$ & $2.33 \mathrm{a}$ & $25.5 \mathrm{bc}$ & $3.86 \mathrm{ab}$ \\
Progeny 2904 & $20.4 \mathrm{a}$ & $7.62 \mathrm{ab}$ & $2.47 \mathrm{a}$ & $31.8 \mathrm{a}$ & $4.24 \mathrm{ab}$ \\
Sweet passion fruit & $16.0 \mathrm{~b}$ & $8.03 \mathrm{ab}$ & $2.21 \mathrm{a}$ & $21.7 \mathrm{c}$ & $4.41 \mathrm{ab}$ \\
Granadilla & $17.9 \mathrm{ab}$ & $8.89 \mathrm{a}$ & $1.55 \mathrm{~b}$ & $24.9 \mathrm{c}$ & $2.61 \mathrm{~b}$ \\
Average & 18.0 & 7.90 & 2.18 & 26.8 & 4.23 \\
C.V. (\%) & 24.0 & 17.9 & 30.3 & 17.7 & 74.7 \\
\hline
\end{tabular}

C.V. = Coefficient of variation; the averages followed by the same uppercase letter in the column, do not differ from each other, based on the Tukey test $(\mathrm{p}<0.05)$.

Table 5. Levels of calcium, magnesium, sulfur, zinc and copper in the leaves of passion fruit grown with or without cow manure, at 120 days after sowing.

\begin{tabular}{cccccc}
\hline Cow manure & $\begin{array}{c}\text { Calcium } \\
\left(\mathrm{g} \cdot \mathrm{kg}^{-1}\right)\end{array}$ & $\begin{array}{c}\text { Magnesium } \\
\left(\mathrm{g} \cdot \mathrm{kg}^{-1}\right)\end{array}$ & $\begin{array}{c}\text { Sulfur } \\
\left(\mathrm{g} \cdot \mathrm{kg}^{-1}\right)\end{array}$ & $\begin{array}{c}\text { Zinc } \\
\left(\mathrm{mg} \cdot \mathrm{kg}^{-1}\right)\end{array}$ & $\begin{array}{c}\text { Copper } \\
\left(\mathrm{mg}^{-1} \mathrm{~kg}^{-1}\right)\end{array}$ \\
\hline With & $16.0 \mathrm{~b}$ & $7.16 \mathrm{~b}$ & $2.27 \mathrm{a}$ & $31.5 \mathrm{a}$ & $5.11 \mathrm{a}$ \\
Without & $20.0 \mathrm{a}$ & $8.72 \mathrm{a}$ & $2.09 \mathrm{a}$ & $22.1 \mathrm{~b}$ & $3.35 \mathrm{~b}$ \\
Average & 18.0 & 7.90 & 2.18 & 26.8 & 4.23 \\
CV (\%) & 24.0 & 17.9 & 30.3 & 17.7 & 74.7 \\
\hline
\end{tabular}

C.V. = Coefficient of variation; the averages followed by the same uppercase letter in the column, do not differ from each other, based on the Tukey test $(\mathrm{p}<0.05)$.

which, in this case, might be considered a good source of these nutrients for the plants.

There are few papers in the scientific literature reporting levels of micronutrients suitable for passion fruit, notably for the P. alata and P. ligularis. According to [20] the appropriate levels of $\mathrm{Zn}, \mathrm{Fe}$ and $\mathrm{Mn}$ in leaf dry matter are 22.0; 116.0 and $80.0 \mathrm{mg} \cdot \mathrm{kg}^{-1}$, respectively. In this sense, the comparison of micronutrient levels of species such as $P$. alata and $P$. ligularis with genotypes of $P$. edulis can lead to an incorrect interpretation of the nutritional status of these crops.

For Zn, the foliar content regarded as suitable is $45-80 \mathrm{mg} \cdot \mathrm{kg}^{-1}$ [21]. Larger values of this nutrient were observed for the genotypes on the substrate without the addition of cow manure, and despite being higher than the 
levels for the genotypes on the substrate with addition of cow manure (Table 5), the values are below the minimum limit value for the crop, according to [21]. While the genotypes, Progeny 2904 and cultivated passion fruit, presented the greatest foliar $\mathrm{Zn}$ levels (Table 4).

The genotype Granadilla on the substrate that did not contain cow manure presented levels of foliar Fe well above those of other genotypes (Table 6). The levels of this micronutrient found in this research are well above those considered suitable for this crop, which, according to [21], are between $100-200 \mathrm{mg} \cdot \mathrm{kg}^{-1}$.

Whereas the appropriate range of $\mathrm{Mn}$ is between $50-200 \mathrm{mg} \cdot \mathrm{kg}^{-1}$ [21], it is verified that sweet passion fruit fertilized with cow manure showed foliar content below the minimum level considered suitable for this crop. While the greatest foliar levels were found for Progeny 2904 and cultivated passion fruit, followed by Progeny 0304 on substrate that did not contain cow manure (Table 6).

The highest foliar Mn levels found for the genotypes on the substrate without cow manure (Table 6) may be associated with a possible reduction of the substrate $\mathrm{pH}$, which was lower when compared to the $\mathrm{pH}$ of the substrate with cow manure, being responsible for the increased solubility of $\mathrm{Mn}$ in the medium.

The sweet passion fruit showed lower foliar content of total phenols $\left(13.1 \mathrm{~g} \cdot \mathrm{kg}^{-1}\right)$ and at the same time showed lower K content compared to other genotypes, when cow manure was not applied (Table 7), being close to the average value of total phenols reported by [22] $\left(11.5 \mathrm{~g} \cdot \mathrm{kg}^{-1}\right)$ who tested arbuscular mycorrhizal fungi inoculation and phosphorus doses for this genotype.

Gobbo-Neto [4] reported that variations in foliar K levels can interfere greater or lesser production of secondary metabolites, depending on the plant species and the type of pathway involved in the metabolite production

Table 6. Levels of iron and manganese in leaves of genotypes of passion fruit grown with or without cow manure, at 120 days after sowing.

\begin{tabular}{|c|c|c|c|c|c|c|}
\hline \multirow{2}{*}{$\begin{array}{l}\text { Genotypes of } \\
\text { passion fruit }\end{array}$} & \multicolumn{2}{|c|}{ Iron $\left(\mathrm{mg} \cdot \mathrm{kg}^{-1}\right)$} & \multirow{2}{*}{ Average } & \multicolumn{2}{|c|}{ Manganese $\left(\mathrm{mg} \cdot \mathrm{kg}^{-1}\right)$} & \multirow{2}{*}{ Average } \\
\hline & $\begin{array}{l}\text { Without } \\
\text { manure }\end{array}$ & With manure & & $\begin{array}{l}\text { Without } \\
\text { manure }\end{array}$ & $\begin{array}{l}\text { With } \\
\text { manure }\end{array}$ & \\
\hline Cultivated passion fruit & $303 \mathrm{Ab}$ & $275 \mathrm{Aa}$ & 289 & 199.0Aa & 63.5Bab & 131.3 \\
\hline Progeny 0304 & $301 \mathrm{Ab}$ & 286Aa & 293 & 192.6Aab & 66.3Bab & 129.4 \\
\hline Progeny 2904 & $262 \mathrm{Ab}$ & 277Aa & 269 & 205.7Aa & 67.3Bab & 136.5 \\
\hline Sweet passion fruit & $250 \mathrm{Ab}$ & $232 \mathrm{Aa}$ & 241 & 102.3Ac & $36.7 \mathrm{Bb}$ & 69.5 \\
\hline Granadilla & $620 \mathrm{Aa}$ & 213Ba & 416 & 148.3Abc & 99.5Ba & 123.9 \\
\hline Average & 347 & 256 & 302 & 169.6 & 66.7 & 118.1 \\
\hline C.V. (\%) & & 26.14 & & & 28.0 & \\
\hline
\end{tabular}

C.V. = Coefficient of variation; the averages followed by the same uppercase letter in the column and lowercase letter on the line, do not differ significantly based on the Tukey test $(\mathrm{p}<0.05)$.

Table 7. Total phenols content in the leaves of genotypes of passion fruit grown with or without cow manure, at 120 days after sowing.

\begin{tabular}{cccc}
\hline \multirow{2}{*}{$\begin{array}{c}\text { Genotypes of } \\
\text { passion fruit }\end{array}$} & \multicolumn{2}{c}{ Total phenols $\left(\mathrm{g} \cdot \mathrm{kg}^{-1}\right)$} & Average \\
\cline { 2 - 4 } Cultivated passion fruit & Without manure & With manure & 21.7 \\
Progeny 0304 & $23.2 \mathrm{Aa}$ & $20.3 \mathrm{Aa}$ & 18.8 \\
Progeny 2904 & $20.5 \mathrm{Aa}$ & $17.1 \mathrm{Aa}$ & 20.7 \\
Sweet passion fruit & $22.0 \mathrm{Aa}$ & $19.5 \mathrm{Aa}$ & 16.4 \\
Granadilla & $13.1 \mathrm{Bb}$ & $19.8 \mathrm{Aa}$ & 19.4 \\
Average & $20.4 \mathrm{Aa}$ & $18.5 \mathrm{Aa}$ & 19.4 \\
C.V. (\%) & 19.8 & 19.0 & 19.1 \\
\hline
\end{tabular}

C.V. = Coefficient of variation; the averages followed by the same uppercase letter in the column and lowercase letter on the line, do not differ significantly based on the Tukey test $(\mathrm{p}<0.05)$. 
process. In the present study, the sweet passion fruit presented increments on total phenols levels and $\mathrm{K}$ when fertilized with cow manure (Table 7). Instead, [20], working with K-deficient sweet passion fruit, observed higher levels of phenolic compound (vitexin) in relation to plants grown in complete nutrient solution.

\section{Conclusions}

The leaf $\mathrm{N}$ content changed depending on the levels of $\mathrm{N}$, organic manure and genotypes used; the contents of $\mathrm{P}$ and $\mathrm{K}$ were greater from the organic fertilizer in all genotypes.

Nutritional requirement for nitrogen is greater for genotypes of the $P$. edulis species in relation to $P$. alata and P. ligulares.

Organic fertilization positively influences total phenol production of sweet passion fruit genotype.

\section{References}

[1] Macoris, M.S., Janzantti, N.S., Garruti, D.S. and Monteiro, M. (2011) Volatile Compounds from Organic and Conventional Passion Fruit (Passiflora edulis F. var flavicarpa Deg.) Pulp. Ciência e Tecnologia de Alimentos, 31, 430-435. http://dx.doi.org/10.1590/S0101-20612011000200023

[2] Oliveira, L.C., Santos, J.A.B., Narain, N., Fontes, A.S., Campos, R.S.S. and Souza, T.L. (2012) Characterization and Extraction of Volatile Compounds from Passion Fruit (Passiflora edulis Sims F. flavicarpa Degener) Processing Wast. Ciência Rural, 42, 2280-2287. http://dx.doi.org/10.1590/S0103-84782012005000103

[3] Vargas, P.N., Hoelzel, S.C. and Rosa, C.S.da. (2007) Determination of Total Polyphenols Content and Antioxidant Activity in Commercial Grape Juices. Alimentos e Nutrição Araraquara, 19, 11-15.

[4] Gobbo-Neto, L. and Lopes, N.P. (2007) Medicinal Plants: Factors of Influence on the Content of Secondary Metabolites. Química Nova, 30, 374-381. http://dx.doi.org/10.1590/S0100-40422007000200026

[5] Freitas, M.S.M., Monnerat, P.H., Vieira, I.J.C. and Carvalho, A.J.C.de. (2007) Flavonoids and Mineral Composition the Leaf in Yellow Passion Fruit Plant in Function of Leaves at Positions in the Branch. Ciência Rural, 37, 1634-1639. http://dx.doi.org/10.1590/S0103-84782007000600020

[6] Freitas, M.S.M., Monnerat, P.H., Carvalho, A.J.C.de. and Vasconcelos, M.A. (2011) Deficiency Symptoms of Macronutrientes and Boron in Sweet Passion Fruit Plant. Revista Brasileira de Fruticultura, 33, 1329-1341. http://dx.doi.org/10.1590/S0100-29452011000400034

[7] Souza, L.B., Heitor, L.C., Santos, P.C.dos., Freitas, J.A.A., Freitas, M.S.M.de., Freitas, S.de.J. and Carvalho, Al.J.C. (2013) Growth, Mineral Composition and Total Phenol of Passiflora Species as Affected by Nitrogen Sources. Bragantia, 72, 247-254.

[8] Cavalcante, L.F., Rodolfo Júnior, F., Beckmann-Cavalcante, M.Z. and Santos, G.P. (2012) Leaf-Macronutrient Status and Fruit Yield of Biofertilized Yellow Passion Fruit Plants. Journal of Plant Nutrition, 35, 176-191. http://dx.doi.org/10.1080/01904167.2012.636121

[9] Marschner, P. (2012) Mineral Nutrition of Higher Plants. Elsevier, San Diego.

[10] Santos, P.C., Lopes, L.C., Freitas, S.J., Sousa, L.B. and Carvalho, A.J.C. (2011) Initial Growth and Nutritional Content of Yellow Passion Fruit Subjected to Fertilization with Different Nitrogen Sources. Revista Brasileira de Fruticultura, 33, 722-728. http://dx.doi.org/10.1590/S0100-29452011000500101

[11] Cavalcante, Í.H.L., Cavalcante, L.F., Santos, G.D., Beckmann-Cavalcante, M.Z. and Silva, S.M. (2012) Impact of Biofertilizers on Mineral Status and Fruit Quality of Yellow Passion Fruit in Brazil. Communications in Soil Science and Plant Analysis, 43, 2027-2042. http://dx.doi.org/10.1080/00103624.2012.693234

[12] Pires, A.A., Monnerat, P.H., Pinho, L.G.R., Zampirolli, P.D., Rosa, R.C.C. and Muniz, R.A. (2009) Effects of Alternative Fertilization on Production Components of Yellow Passion Fruit. Acta Scientiarum Agronomy, 31, 655-660.

[13] de Carvalho, A.J.C., Monnerat, P.H., Martins, D.P., Bernardo, S. and da Silva, J.A. (2002) Leaf Nutrient Contents in Yellow Passionfruit in Response to Nitrogen Fertilization, Irrigation and Sampling Time. Scientia Agricola, 59, 121127.

[14] Jackson, M.L. (1965) Soil Chemical Analysis. Prentice Hall, New Jersey.

[15] Anderson, J.D. and Ingram, J.S.I. (1996) Tropical Soil Biology and Fertility: A Handbook of Methods. CAB International, Wallingford.

[16] Aita, C. and Giacomini, S.J. (2003) Crop Residue Decomposition and Nitrogen Release in Single and Mixed Cover Crops. Revista Brasileira de Ciência do Solo, 27, 601-612. http://dx.doi.org/10.1590/S0100-06832003000400004

[17] Moraes, J.C.B., Salcedo, I.H. and Sousa, V.F. (2011) Potassium Doses by Drip Irrigation in the Nutritional State of Yellow Passion Fruit. Revista Brasileira de Engenharia Agrícola e Ambiental, 15, 763-770. 
[18] Rosolem, C.A., dos Santos, F.P., Foloni, J.S.S. and Calonego, J.C. (2006) Soil Potassium as Affected by Fertilization over the Millet Straw and Simulated Rain. Pesquisa Agropecuária Brasileira, 41, 1033-1040. http://dx.doi.org/10.1590/S0100-204X2006000600020

[19] de Carvalho, A.J.C., Martins, D.P., Monnerat, P.H. and da Silva, J.A. (2001) Nutrients Contents in the Leaf Dry Matter Associated with Seasonal Phenology, Potassium Fertilization and Irrigation Depths in Yellow Passionfruit. Revista Brasileira de Fruticultura, 23, 403-408. http://dx.doi.org/10.1590/S0100-29452001000200041

[20] Freitas, M.S.M., Monnerat, P.H. and Vieira, I.J.C. (2008) Mineral Deficiency in Passiflora alata Curtis: Vitexin Bioproduction. Journal of Plant Nutrition, 31, 1844-1854. http://dx.doi.org/10.1080/01904160802325552

[21] IFA-International Fertilizer Industry Association (1992) World Fertilizer Use Manual. BASF Agricultural Research Station, Limburgerhaf.

[22] Netto, A.F.R., Freitas, M.S.M., Martins, M.A., de Carvalho, A.J.C. and Vitorazzi Filho, J.A. (2014) Total Phenols in Passiflora alata Curtis Inoculated with Mycorrhizal Fungi. Revista Brasileira de Plantas Medicinais, 16, 1-9. 